\title{
Gap in Knowledge and Adoption of Post Harvest Technologies of Maize among Farmers and Farm Women
}

\author{
Chamandeep Kaur ${ }^{1}$, Dhriti Solanki ${ }^{2}$ and L. R. Choudhary ${ }^{3 *}$ \\ ${ }^{1}$ Department of Home Science, KVK, Sawai Madhopur, Rajasthan, India \\ ${ }^{2}$ Department of HECM, College of H.Sc, MPUAT, Udaipur, Rajasthan, India \\ ${ }^{3}$ Department of Agriculture Extension, KVK, Gudamalani, Barmer, Rajasthan, India \\ *Corresponding author
}

\section{A B S T R A C T}

\section{Keywords}

Female member, Knowledge, Global challenges,

Employment,

Transformation

Article Info

Accepted:

04 November 2019

Available Online:

10 December 2019
The present study was undertaken to assess gap in knowledge and adoption of post harvest technologies of maize. The study was conducted in two purposively selected districts viz. Udaipur and Chittorgarh of Agroclimatic zone IV A of Rajasthan. Two panchayat samities from each district were selected purposively and three villages from each panchayat samiti were selected on random basis. Thus, there were total six villages from each district and total 12 villages from both the districts. Fifteen farm families from each village and 90 farm families from each district were selected. One male and one female member of the farm family who was actively involved in maize cultivation were included in the sample. Thus, total sample for the present study was 360 respondents (180 farmers and 180 farm women). The interview schedule consisted of four sections i.e. personal characteristics of the respondents, Knowledge of the respondent about post harvest technologies, Extent of adoption and gap in post harvesting technologies by the farm families. Gap in Post harvest technologies, in case of farmers the overall gap in knowledge and adoption was found to be 8.21 per cent with knowledge significantly higher than the adoption. In case of farm women, the overall gap in knowledge and adoption was 30.41 per cent with adoption significantly higher than the knowledge.

\section{Introduction}

At the dawn of the new millennium, the evidence is over whelming that an agricultural transformation is essential to meet the global challenges of feeding the world's growing population, conserving the environment and reducing the poverty. Such a transformation is urgently needed in large agrarian economy such as India where it will have to occur at level of small-holder farmers so that their complex farming system can be made more productive and efficient in the use of resources. (Intodia and Mathur, 2000-2002). Production and consumption of agriculture commodities has a diverse geographical 
distribution. Due to diverse agro-climatic condition the country is fortunate enough to produce number of cereal crops viz. wheat, rice, sorghum, bajra and maize. India is among the top ten countries in the world with respect to production of cereals. Among the cereal crops, India stands on $6^{\text {th }}$ position with respect to production of maize (FAO STAT, 2013). Maize is third most important cereal in the country after wheat and rice.

It contributes nearly 9 per cent in the national food basket and more than ì 100 billion to the agricultural GDP at current price apart from generating employment to over 100 million man days at the farm and downstream agricultural and industrial sectors. In addition to staple food for human being and quality feed for animals, maize serves as a basic raw material as an ingredient to thousands of industrial products that includes starch, oil, protein, alcoholic beverages, food sweeteners, pharmaceutical, cosmetic, textile, gum, package and paper industries. Currently it is cultivated over an area of 8.75 million hectare with 21.73 million tones production and an average yield of $25.40 \mathrm{q} / \mathrm{ha}$ (Directorate of Economics and Statistics, 2012). Rajasthan ranks first in respect of area, where in this crop occupies 10.51 lakhs ha area and 19.44 million tones production (Directorate of Agriculture, 2011-12).

\section{Materials and Methods}

The present study was conducted in the Agroclimatic zone IV A i.e. Sub- humid Southern Plain and Aravali Hills of Rajasthan State. Zone IV A covers all the tehsils of Bhilwara and Rajsamand districts, all tehsils of Udaipur district except Dhariyawad, Salumber and Sarada, all tehsils of Chittorgarh district and Aburoad and Pindwara tehsils of Sirohi district. Out of these, two districts namely Udaipur and Chittorgarh were selected purposively on the basis of highest production of maize. Zone IV- A of Rajasthan covers fourteen panchayat samities of Udaipur and eleven of Chittorgarh district. Out of these, two panchayat samities from each district were selected purposively on the basis of highest production of maize. Thus, from Udaipur district, Mavli and Girwa panchayat samities and from Chittorgarh district, Begu and Chittorgarh panchayat samities were selected. In each district, panchayat samiti wise list of villages was prepared and from the list three villages from each panchayat samiti were selected on random basis. Thus, there were six villages from each district making total 12 villages from both the districts. For selection of sample, a comprehensive list of maize growers was prepared from each identified village with the help of village Patwari and Agricultural Supervisor of the respective village and was categorized as small, marginal and large farmers on the basis of land holding. From each category, five farm families were selected from each village on random basis. Thus, there were 15 farm families from each village and 90 farm families from each district. One male and one female member of the farm family who was actively involved in maize cultivation was included in the sample. Thus, total sample for the present study was 360 respondents (180 farmers and 180 farm women).

\section{Results and Discussion}

Technology generation and technology transfer are widely acknowledged as crucial for accelerating production. However, technology transfer has been given lower priority, perhaps because of deficiencies in technology transfer. Most of the techniques and practices remain confined to four walls of laboratories and research farms and those carried out to the farmers get distorted or lopped off considerably by the time and stage they actually are adopted at final level. Often, adoption of these practices is in piece meal 
and several necessary components of the package are either not adopted at all or adopted below the recommended levels.

Cursory of Table 1 depicts that there was significant difference in overall knowledge and adoption score of post harvest technologies of maize by of the farmers as the calculated t-value found to be significant at 1 per cent level of significance. The overall adoption score (59.44) was found to be lower than the knowledge score (67.65 MPS) with a difference of 8.21 per cent. Component wise analysis of data reveals that there was significant difference in knowledge and adoption scores in all the components except use of rodenticides in which the difference was found to be non-significant. In component time of harvesting the adoption (100 MPS) was higher than the knowledge (93.33 MPS) with a difference of 6.67 per cent. In components storage structure and use of fumigants the knowledge (62.55 and 68.00 MPS) was higher the adoption (45.00 and 26.67 MPS) with a difference of 17.55 and 41.33 per cent, respectively. The reason for this was that the farmers knew about improved storage structure but they had not adopted it due to high cost. Similarly some of the farmers in spite of having knowledge about fumigants have not adopted it due to its toxicity. In component, consideration in storage of grains in the knowledge score was 69.33 per cent and adoption score was 63.89 per cent with a gap of 5.44 per cent. In component use of rodenticides no significant difference in knowledge and adoption was observed. The knowledge of the farmers was significantly higher than the adoption score in all the components except time of harvesting in which the adoption score was higher than the knowledge.

Gap in knowledge and adoption of post harvest technologies of maize among farm women

Perusal Table 2 depicts that there was significant difference in overall and component wise knowledge and adoption scores of improved post harvest technologies by the farm women as the calculated t-value was found to be significant at 1 per cent level of significance.

The overall adoption score (59.44 MPS) was higher as compared to knowledge score (29.03 MPS) with a difference of 30.41 per cent. Similarly the adoption scores were significantly higher than the knowledge scores in all the components.

Table.1 Gap in knowledge and adoption of post harvest technologies of maize among farmers

\begin{tabular}{|c|c|c|c|c|c|}
\hline S.No & Components & $\begin{array}{c}\text { Knowledge } \\
\text { (MPS) }\end{array}$ & $\begin{array}{c}\text { Adoption } \\
\text { (MPS) }\end{array}$ & Gap (\%) & t-value \\
\hline $\mathbf{1}$ & Time of harvesting & 93.33 & 100.00 & 6.67 & $3.58^{* *}$ \\
\hline $\mathbf{2}$ & Storage structure & 62.55 & 45.00 & 17.55 & $11.25^{* *}$ \\
\hline $\mathbf{3}$ & Use of fumigants & 68.00 & 26.67 & 41.33 & $16.74^{* *}$ \\
\hline $\mathbf{4}$ & Use of rodenticides & 75.56 & 73.33 & 2.22 & 0.75 NS \\
\hline $\mathbf{5}$ & $\begin{array}{c}\text { Consideration in } \\
\text { storage of grains }\end{array}$ & 69.33 & 63.89 & 5.44 & $3.37 * *$ \\
\hline & Overall & $\mathbf{6 7 . 6 5}$ & $\mathbf{5 9 . 4 4}$ & $\mathbf{8 . 2 1}$ & $\mathbf{7 . 5 7 * *}$ \\
\hline
\end{tabular}

** Significant at $1 \%$ level of Significance

NS Non Significant 
Table. 2 Gap in knowledge and adoption of post harvest technologies of maize among farm women

\begin{tabular}{|c|c|c|c|c|c|}
\hline S.No & Components & Knowledge & Adoption & Gap $(\%)$ & t values \\
\hline $\mathbf{1}$ & Time of harvesting & 13.33 & 100.00 & 86.67 & $34.11^{* *}$ \\
\hline $\mathbf{2}$ & Storage structure & 35.56 & 45.00 & 9.44 & $7.90^{* *}$ \\
\hline $\mathbf{3}$ & Use of fumigants & 17.33 & 26.67 & 9.33 & $3.13^{* *}$ \\
\hline $\mathbf{4}$ & Use of rodenticides & 28.89 & 73.33 & 44.44 & $16.84 * *$ \\
\hline $\mathbf{5}$ & Consideration in & 40.00 & 63.89 & 23.89 & $13.34 * *$ \\
& storage of grains & & & & \\
\hline & Overall & $\mathbf{2 9 . 0 3}$ & $\mathbf{5 9 . 4 4}$ & $\mathbf{3 0 . 4 1}$ & $\mathbf{3 7 . 0 0 * *}$ \\
\hline
\end{tabular}

** Significant at $1 \%$ level of Significance

NS Non Significant

On the basis of findings it could be concluded that gap in knowledge and adoption scores of the farmers was not much higher as compared to the farm women. The farm women had a wide gap in their knowledge and adoption with adoption scores significantly higher than the knowledge scores. The possible reason for this may be that since agriculture is a family enterprises decision to adopt a technology is generally taken by the male members.

\section{References}

Intodia, S. L. and Mathur, P. 2000-2002. A Study on assessment and refinement of crop production technologies generated by agricultural universities for different Agro-climatic zones of Rajasthan. A Project Report submitted to Maharana Pratap University of Agriculture and Technology, Udaipur, Rajasthan. pp. 17.
FAO STAT. 2013. Food and Agriculture Organization of the United Nation retrieved from http://Fao3.fao.org/faostat-gateway/go/to on October $20^{\text {th }}, 2013$

Directorate of Agriculture.2011-2012. Agriculture Statistics at a Glance, Department of Agriculture, Government of Rajasthan, Jaiapur retrieved from www.krishi.rajasthan.gov.in/Department /Agriculture/AGRICULTURAL_STATI STICS_2011_12.pdf on 24th October, 2013.

Directorate of Economics and Statistics. 2012. Agriculture Statistics at a Glance. Department of Agriculture and Cooperation, Ministry of Agriculture, Government of India retrieved from eands.dacnet.nic.in/Publication12122012/Agriculture_at_a_Glance\%2020 12/page-139-140 on 24th October, 2013.

\section{How to cite this article:}

Chamandeep Kaur, Dhriti Solanki and Choudhary, L. R. 2019. Gap in Knowledge and Adoption of Post Harvest Technologies of Maize among Farmers and Farm Women. Int.J.Curr.Microbiol.App.Sci. 8(12): 97-100. doi: https://doi.org/10.20546/ijcmas.2019.812.015 